\title{
The Effect of Autogenic Relaxation Therapy on Post-Flood Stress in Communities in Widang District, Tuban District
}

\author{
Miftahul Munir \\ Lecturer of Nursing Bachelor Program STIKES Nahdlatul Ulama Tuban \\ Email: bahranmifanda69@gmail.com
}

\begin{abstract}
Natural disasters can occur around the world including indonesi, a natural disaster that often happens is flooding. Floods can have an impact on a person's life either pleasant or unpleasant will remain on the individuals. Dose that will emphasize the possibility of society especially in elderly. This problem needs to be reused immediately to a normal level and will not remember the past events. The purpose of this study to determine the effect of Autogenic Therapy on stress in the elderly in Patihan Village Widang District Tuban.

The research method used is cross sectional. The population used in this study is Elderly in Patihan Village Widang District Widang in accordance with the inclusion criteria of 25, with a large sample of 20 respondents using simple random sampling technique. Independent variable in this research is autogenic therapy, whereas dependent variable is stress on post-flood lanscas, that is data used in data of Questionnaire and SOP, research analysis using Wilcoxon test.

The results showed There Characteristics of Autogenic Therapy on stress in elderly in Patihan Village Widang District Tuban. This is evidenced by statistical analysis test results wilcoxon $\alpha=0.05$ obtained $p$ value $=0.008$ where $0.008 \leq 0.05$ $(p \leq \alpha)$ Medium degree of significance with a negative direction.

The results of this study can be used as an alternative self-treatment or posyandu elderly, in dealing with post-flood stress.
\end{abstract}

\section{Keywords: Autogenic Relaxation Therapy, Communities, Post-Flood Stress.}

\section{INTRODUCTION}

Natural disasters can occur throughout the world, including in the territory of Indonesia. Geographically, Indonesia is a country prone to natural disasters such as earthquakes, tsunamis, floods, volcanic eruptions and landslides that often hit Indonesia. Natural disasters that are often faced by Indonesian people are floods. High risk floods threaten the lives of the residents and damage the existing infrastructure. These changes can cause stress. Stress experienced can lead to pressure or demands experienced by individuals so that they adapt or adapt. Stress has broad implications for physical and psychological problems. The effects of stress can cause adjustment disorders that involve the adaptive mal reaction to stress. This disturbance is found in people who have witnessed the destruction of their homes and environment by natural disasters, such as floods, earthquakes, tornadoes, and so on.

Relaxation is a condition where a person feels mentally and physically free from tension and stress. Relaxation technique aims to 
enable individuals to control themselves when there is a sense of tension and stress that makes individuals feel in uncomfortable conditions (Mustikarani et al., 2017). One method of reducing stress in the elderly due to floods.

This method is carried out with a psychological approach that will support increased welfare and independence. Trauma healing therapy is really needed in Patihan Village which is a village prone to natural disasters, one of which is flood. Stress in the elderly cannot be allowed to drag on, so that the victim can continue his life normally, in Therapy Healing there are various methods to reduce stress levels in the elderly is to do a relaxation approach Autogenic is one of relaxation based on passive concentration using body perception (Emaliyawati, Prawesti, Yosep, \& Ibrahim, 2016). Relaxation techniques by using words or short sentences that can make the mind calm (Nurhayati, Andriyani, \& Malisa, 2015)

\section{METHOD}

This research design is an experimental research with a pre- experimental design using "one group pre-post test design" research design,

The population in this study were the elderly in Patihan village, Widang sub-district, Tuban, which amounted to 25 elderly. The sampling technique used in this study uses Simple Random Sampling based on inclusion criteria. Inclusion criteria are the elderly, the elderly who are willing to be respondents, the elderly who are willing to be respondents. The elderly who suffer from stress disorders. The instrument used in this study is the Standard Operational Procedure (SOP) is a guideline or reference for doing work in accordance with the steps of the Autogenous Relaxation Therapy measures.

Data collection in this study was carried out primarily starting with permission from the institution, then after obtaining permission from the Village Head Data processing in this study uses the following stages: Editing, Coding, Scoring and Tabulation. Bivariate data analysis with Wilcoxon test.

\section{RESULTS AND DISCUSSION}

Table 1 Distribution of Stress Frequency in Elderly after flood before Autogenic Relaxation Therapy in Widang Tuban Subdistrict

\begin{tabular}{clcc}
\hline No & \multicolumn{1}{c}{ Stress } & n & $\mathbf{( \% )}$ \\
\hline 1. & Mild stress & 9 & $42,1 \%$ \\
2. & Moderate stress & 4 & $21,1 \%$ \\
3. & Severe stress & 6 & $31,6 \%$ \\
4. & Stress Is Quite Heavy & 1 & $5,3 \%$ \\
\multicolumn{2}{c}{ Total } & 20 & $100 \%$ \\
\hline
\end{tabular}

Data source: Primary data (2018)

Based on the table above shows that of the 20 respondents before being given the Autogenic Relaxation therapy the majority were $9(42.1 \%)$ respondents had a mild stress category.

Based on research conducted by researchers in Widang Tuban 
Subdistrict, a prominent psychological disorder in the elderly after flooding is experiencing a repeat of the experience of trauma, shown by often remembering the sad events that they have experienced, anxiety and excessive fear. Some of the respondents also experienced increased tensions such as difficulty in starting sleep at night, difficulty concentrating, avoiding certain places which he said were dangerous and also tried to avoid activities that the respondents usually did to reduce the trauma caused by flooding. Most of the respondents fall into mild stress, although floods often occur every year. Psychological disorders experienced by the elderly are often not identified and have not been treated properly because of the environment they live in also consider it normal. If this is not addressed, it will prevent the elderly from living their lives enthusiastically. The characteristics of the elderly in this study include biological, psychological, socio-cultural factors. Stress can occur at any age. The most important factor in this research is psychological factors (Zwolinska et al., 2016) . Psychological factors include verbal ability moral knowledge, personal to himself, encouragement or motivation (Nur Rohmah, 2012). Shown with headaches due to insomnia, blood pressure that is too low and too high and difficult to concentrate because people in a state of stress and stress for a long time, usually have difficulty concentrating on the job or other (Priyo, Margono, \& Hidayah, 2017).

Table 2 Distribution of Stress Frequency in Elderly after flood after Autogenic Relaxation Therapy in Widang Tuban District

\begin{tabular}{clcc}
\hline No & \multicolumn{1}{c}{ Stress } & f & $\mathbf{( \% )}$ \\
\hline 1. & Mild stress & 11 & $55 \%$ \\
2. & Moderate stress & 7 & $35 \%$ \\
3. & Severe stress & 2 & $10 \%$ \\
4. & Stress Is Quite Heavy & 0 & $0 \%$ \\
$\quad$ Total & 20 & $100 \%$ \\
\hline
\end{tabular}

Data source: Primary data (2018)

Based on the table above shows that the above can be seen that of the 20 respondents after being given Autogenic Relaxation therapy most of the $11(55 \%)$ respondents had a mild stress category.

Factors that influence stress in the elderly, namely psychology. Psychological factors themselves include: verbal ability, moral knowledge, personal to himself, encouragement or motivation (Syamsiah \& Muslihat, 2015). Shown with headaches due to insomnia, blood pressure that is too low and too high and difficult to concentrate because people in a state of stress and stress for a long time, usually have difficulty concentrating on the job or other. In helping clients who are experiencing mild or moderate physical or psychological tension or stress, autogenic relaxation therapy is one of the recommended therapies. This therapy emphasizes the practice of regulating the mind, a relaxed position and regulating breathing patterns. In addition it can also be 
done by imagining (imagery) pleasant sensations in certain parts such as the head, chest, arms, back, toes or hands, and wrists. The sensations imagined are like a feeling of warmth, weakness or relax on the right side, also a feeling of relief because of deep and slow breaths. The sensation that is felt is accompanied by a pleasant imagination for example about a beautiful view, a calm lake and so on, so that one will feel free mentally and physically with tension and stress
(Yulianto, Sari, \& Lestari, 2013). The impact of this autogenic relaxation therapy can help individuals consciously divert commands from that individual. This can help fight the effects of stress that are harmful to the body. Autegenic relaxation techniques have a basic idea which is to learn how to divert the mind based on suggestions so that individuals can get rid of stress responses that interfere with thoughts (Rosida, Imardiani, \& Wahyudi, 2019).

Table 3 Cross Table of the Effects of Autogenic Relaxation Therapy on PostFlood Stress in the Elderly District of Widang Tuban 2018

\begin{tabular}{|c|c|c|c|c|c|}
\hline \multirow{2}{*}{$\begin{array}{c}\text { Autogenic } \\
\text { Relaxation } \\
\text { Therapy }\end{array}$} & \multicolumn{4}{|c|}{ Stress } & \multirow[t]{2}{*}{ Total } \\
\hline & Mild stress & $\begin{array}{l}\text { Moderate } \\
\text { stress }\end{array}$ & $\begin{array}{l}\text { Severe } \\
\text { stress }\end{array}$ & $\begin{array}{c}\text { Stress Is } \\
\text { Quite } \\
\text { Heavy }\end{array}$ & \\
\hline Pre-test & $\begin{array}{c}9 \\
(42,1 \%)\end{array}$ & $\begin{array}{c}4 \\
(21,1 \%)\end{array}$ & $\begin{array}{c}6 \\
(31,6 \%) \\
\end{array}$ & $\begin{array}{c}1 \\
(5,3 \%) \\
\end{array}$ & $\begin{array}{c}20 \\
(100 \%)\end{array}$ \\
\hline Post-test & $\begin{array}{c}11 \\
(55 \%)\end{array}$ & $\begin{array}{c}7 \\
(35 \%)\end{array}$ & $\begin{array}{c}2 \\
(10 \%)\end{array}$ & $\begin{array}{c}0 \\
(0 \%)\end{array}$ & $\begin{array}{c}20 \\
(100 \%)\end{array}$ \\
\hline & $\begin{array}{c}20 \\
(96,2 \%)\end{array}$ & $\begin{array}{c}11 \\
(56,1 \%)\end{array}$ & $\begin{array}{c}8 \\
(41,6 \%)\end{array}$ & $\begin{array}{c}1 \\
(5,3 \%)\end{array}$ & $\begin{array}{c}40 \\
(200 \%)\end{array}$ \\
\hline
\end{tabular}

Table 3 above shows that before being given treatment, some respondents who have a category of mild stress are increasing enthusiasm, sharper vision as many as $9(42 \%)$ and after being given treatment of respondents who have a category of mild stress as many as $11(55 \%)$.

The results of this study prove that there is a significant influence in providing autogenic relaxation therapy to stress in post-flood elderly in Patihan Village, Widang Tuban District.

The elderly stated that autogenic relaxation therapy was also effective to reduce stress and muscle tension and made it possible to cope with lowering blood pressure and headaches, and with this relaxation therapy approach the elderly were able to do their activities comfortably (Kusyati, 2012).

\section{CONCLUSION}

Autogenic relaxation therapy is effectively used for stress in postflood elderly. This implies that autogenic relaxation therapy can be used as an alternative therapy that can be used by nurses or themselves for handling psychological disorders such as stress and muscle tension and may be able to cope with lowering blood pressure and headaches in the 
Jurnal $\mathcal{M} I \mathcal{D P R O}$

Volume 12 No.1 Juni 2020

elderly before pharmacological treatment.

\section{SUGGESTION}

It is expected that respondents and families seek information or apply precisely about simple therapies that can be used in dealing with stress in the elderly after flooding.

\section{BIBLIOGRAPHY}

Emaliyawati, E., Prawesti, A., Yosep, I., \& Ibrahim, K. (2016). Manajemen Mitigasi Bencana dengan Teknologi Informasi di Kabupaten Ciamis. Jurnal Keperawatan Padjadjaran. https://doi.org/10.24198/jkp.v4n 1.8

Kusyati, E. A. (2012). Efektifitas Teknik Relaksasi Nafas Dalam Terhadap Tingkat Nyeri Persalinan Kala I di Wilayah Kerja PUSKESMAS Tlogosari Wetan Semarang Tahun 2012. Jurnal Kebidanan STIKES Karya Husada Semarang.

Mustikarani, Karunia, N., Wulandari, Yunita, Setyowati, Dwi, Z., \& Rakhmawati, N. (2017). Kombinasi Guided Imagery and Music ( GIM ) Dan Relaksasi Autogenik Terhadap Nyeri Pada Pasien Cedera Kepala. Adi Husada Nursing Jurnal.

Nur Rohmah, A. I. (2012). Kualitas Hidup Lanjut Usia. Jurnal Keperawatan.

Nurhayati, N., Andriyani, S., \& Malisa, N. (2015). Relaksasi Autogenik Terhadap Penurunan Skala Nyeri Pada Ibu Post Operasi Sectio Saecarea. Jurnal
Skolastik Keperawatan.

Priyo, Margono, \& Hidayah, N. (2017). Terapi Relaksasi Autogenik Untuk Menurunkan Tekanan Darah dan Sakit Kepala pada Lansia Hipertensi di Daerah Rawan Bencana Merapi. Urecol.

Rosida, L., Imardiani, I., \& Wahyudi, J. T. (2019). PENGARUH TERAPI RELAKSASI AUTOGENIK TERHADAP KECEMASAN PASIEN DI RUANG INTENSIVE CARE UNIT RUMAH SAKIT PUSRI PALEMBANG. Indonesian Journal for Health Sciences. https://doi.org/10.24269/ijhs.v3i 2.1842

Syamsiah, N., \& Muslihat, E. (2015). Pengaruh Terapi Relaksasi Autogenik Terhadap Tingkat Nyeri Akut Pada Pasien Abdominal Pain Di Igd Rsud Karawang 2014. Jurnal Ilmu Keperawatan. https://doi.org/10.1136/bmj.d44 44

Yulianto, Sari, S. M., \& Lestari, Y. A. (2013). Pengaruh Terapi Relaksasi Autogenik Terhadap Perubahan Tekanan Darah Pada Lansia Dengan Hipertensi. Jurnal Keperawatan \& Kebidanan - Stikes Dian Husada Mojokerto.

Zwolinska, Z., Parafinska, Z., Zwerling, C., Burmeister, L. F., Jensen, C. L. M., Zuo, Z. Q., ... Zatoński, W. A. (2016). THE SUICIDE SYNDROME FARMER,R, HIRSCH,S. PloS One.https://doi.org/10.1111/ajr. 12187 